\title{
Cloning of the gene for a carbohydrate oxidase from Lactuca sativa in the yeasts Saccharomyces cerevisiae and Pichia pastoris
}

\author{
Vojin M. Tadić ${ }^{1}$, Ana Marija J. Balaž ${ }^{2}$, Marija P. Petrić ${ }^{1}$, Snežana M. Milošević ${ }^{1}$, Nevena D. Zelenović ${ }^{3}$, \\ Martin Z. Raspor ${ }^{1}$, Jovan M. Tadić ${ }^{4}$, Radivoje M. Prodanović ${ }^{2}$ \\ ${ }^{1}$ Department for Plant Physiology, Institute for Biological Research "Siniša Stanković", University of Belgrade, Belgrade, \\ Serbia \\ ${ }^{2}$ Department for Biochemistry, Faculty of Chemistry, University of Belgrade, Belgrade, Serbia \\ ${ }^{3}$ Institute for Chemistry, Technology and Metallurgy, University of Belgrade, Belgrade, Serbia \\ ${ }^{4}$ Department of Global Ecology, Carnegie Institution for Science, Stanford, CA, USA
}

\begin{abstract}
We have cloned the gene for carbohydrate oxidase ( $\mathrm{CHO}$ ) from Lactuca sativa in two species of yeasts (Saccharomyces cerevisiae and Pichia pastoris). The synthetic gene for the carbohydrate oxidase (1821 bp) from L. sativa cloned into the vector pUC57 and inserted into plasmids pYES2 and pGAP using Escherichia coli DH5 $\alpha$ strain. The $P$. pastoris strain $\mathrm{X}-33$ and the $\mathrm{S}$. cerevisiae strain InvSC1 were used for extracellular expression of $\mathrm{CHO}$. After transformation of $P$. pastoris X-33 with CHO-pGAP construct none of the colonies showed $\mathrm{CHO}$ activity. Two samples displayed a band which did not exist in the sample with the empty vector similar to the molecular weight of $\mathrm{CHO}$. The $S$. cerevisiae strain InvSC1 has been also transformed with CHO-pYES constructs. Three colonies grew on the plate with cells transformed with the construct. One of the samples showed a band corresponding to about $110 \mathrm{kDa}$, but no $\mathrm{CHO}$ activity was recorded in this case either. Cloning of the foreign genes and heterologous expression in yeasts is widely used in biotechnology, but sometimes can be very dependent on the gene sequence and strain used. In order to obtain active $\mathrm{CHO}$ enzyme the further studies on purification and refolding of expressed protein are necessary.
\end{abstract}

Keywords: Saccharomyces cerevisiae, Pichia pastoris, carbohydrate oxidase, glycosylation.

\section{SCIENTIFIC PAPER}

UDC 635.52:575:577:663

Hem. Ind. 69 (6) 689-701 (2015)

doi: 10.2298/HEMIND140823003T

Available online at the Journal website: http://www.ache.org.rs/HI/

Carbohydrate oxidase ( $\mathrm{CHO}$ ) from lettuce (Lactuca sativa) is an enzyme that has not been examined in detail. Very little is known about its structure and function. $\mathrm{CHO}$ belongs to the large family of carbohydrate oxidases which oxidize sugars. Length of the polypeptide sequence varies depending on the source. Some carbohydrate oxidases have long polypeptide chains (418 to 475 amino acids), while some authors mention up to 540 amino acids polypeptide sequences [1-3]. One of the domains is a flavin cofactor binding domain, and the second is a substrate binding domain. Most of substrate oxidation occurs through a so-called ping-pong mechanism [4]. The Michaelis-Menten constant and $V_{\max }$ vary depending on the substrate used, and on the natural source from which enzyme was obtained. $K_{\mathrm{m}}$ may be from $0.175 \mathrm{mM}$ for glucose up to $11 \mathrm{mM}$ for lactose and $50 \mathrm{mM}$ for galactose. According to some authors, the $K_{\mathrm{m}}$ for lactose is $0.066 \mathrm{mM}$ [1,3$-5]$. The temperature and $\mathrm{pH}$ optimum of the enzyme

Correspondence: V.M. Tadić, Department for Plant Physiology, Institute for Biological Research "Siniša Stanković", University of Belgrade, Bulevar despota Stefana 142, 11000 Belgrade, Serbia.

E-mail: vojin.tadic@ibiss.bg.ac.rs

Paper received: 23 August, 2014

Paper accepted: 10 December, 2014 are also diverse. The most common data in the studies mention a temperature optimum of around $38{ }^{\circ} \mathrm{C}$ [4]. The $\mathrm{pH}$ optimum displays two peaks, the first one located at $\mathrm{pH}$ 6.0-6.5, and the other one at $\mathrm{pH}$ 9-10.5 $[6,7]$.

All the carbohydrate oxidases have found great application in various fields of industry. Examples of such enzymes are glucose oxidase, L-glucono lactone oxidase, hexose oxidase, lactose oxidase, glucoologosaccharide-oxidase and pyranose oxidase. All of mentioned enzymes, except glucose oxidase and pyranose oxidase, belong to the family of vanillyl alcohol oxidases.

Data on $\mathrm{CHO}$ relative molecular mass are also diverse depending on the source of the enzyme. Moreover, recombinant proteins have higher molecular weight. Proteins derived from expression vectors such as yeasts $S$. cerevisiae or $P$. pastoris, have a higher degree of glycosylation. The recombinant enzyme, expressed in P.pastoris, contains up to $14 \mathrm{~N}$-linked mannose residues [8]. The relative molecular weight of the carbohydrate oxidase from various species of fungi, bacteria and plants has been found to vary between 45 and $65 \mathrm{kDa}$ [1-4]. CHO catalyzes the oxidation of the primary alcohol groups in monosaccharides and oligosaccharides, with the reduction of molecular oxygen to 
hydrogen peroxide. The enzyme is capable of generating hydrogen peroxide using cellobiose as substrate. However, this enzyme does not oxidize fructose. Essential substrate structure is a six-member pyranose monosaccharide ring and the $\mathrm{OH}$ group on the second carbon atom in the equatorial position $[1,8,9]$.

$\mathrm{CHO}$ may be applied to the diagnosis, particularly in biosensors for the determination of glucose in the blood, in the food industry, agriculture, production of bread and detergents and in various other industrial areas. The drawback of this enzyme is the low concentrations in natural sources [10]. Also, natural enzymes often do not meet industrial requirements. Various methods of recombinant technology have been developed for the synthesis of these enzymes. Apart from the necessary quantities, the enzyme must have a high stability and activity, particular substrate specificity and high selectivity.

Very little is known about the structure and activities of $\mathrm{CHO}$ from lettuce and its role in nature can be easily described through examples of related enzymes. All members of the large family of CHO's have the same role: oxidation of sugar. Today, the best known and most widely applied enzymes are glucose oxidase, galactose oxidase and hexose oxidase.

The yeast $P$. pastoris has become one of the most used eukaryotic organisms for the production of recombinant proteins. Many authors emphasize that $P$. pastoris is easy to grow and can reach a high density of cells, which is of great industrial interest. In addition, this system has strong regulated promoters and has the ability of secreting foreign proteins. Also, it has the possibilities of posttranslational modifications in the form of glycosylation and formation of disulfide bonds $[11,12]$. However, the high density of cells raises several problems such as transfer of oxygen, which is the main limiting factor. The high cell density is a source of stress which could lead to a decrease in cell viability and productivity and increase cell lysis. Another problem associated with the secretion of heterologous protein is the retention of a certain amount of product in the cells [13].

Most $P$. pastoris expression systems use the methanol-induced alcohol oxidase (AOX1) promoter. Upon induction by methanol, the relative amount of AOX in total soluble proteins can typically rise up to $30 \%$. AOX1 and $A O X 2$ genes encode a functional enzyme, except that the AOX1 makes $95 \%$ of the AOX expressed due to the strength of its promoter. Therefore, systems that use pAOX1 take priority in the expression of foreign proteins [12].

Unlike the AOX1 system, where the production is limited by the availability of the protein in the methanol induction phase, the glyceraldehyde 3-phosphate dehydrogenase constitutive promoter (GAP) system of biomass and protein synthesis occurred simultaneously without methanol. While conditions during the induction phase of the AOX1 system must be strictly controlled, the GAP system has minimum requirements. For extracellular expression, a vector derived from $S$. cerevisiae $\alpha$-factor is used, that contains a sequence encoding a secretion signal linked to the foreign gene [11]. Several studies have shown that pGAP is more efficient of PAOX1 for the production of proteins $[12,14]$.

One of the main disadvantages of the $P$. pastoris expression system is a post-secretory proteolytic degradation of the recombinant products. Reducing the number of cells during the induction phase is correlated with the accumulation of intracellular reactive oxygen species, especially of formaldehyde and hydrogen peroxide, which are by-products of the metabolism of methanol $[12,15]$.

The yeast $S$. cerevisiae is the most important eukaryotic model organism for molecular genetic studies. It is used in the production of bread and beer, and it is considered safe for the production of proteins for use in medicine or in the food industry. It is easy for genetic manipulation, which makes it popular for cloning and expression of eukaryotic proteins [12,16,17]. Beside $P$. pastoris and Hansenula polymorpha, S. cerevisiae is the most commonly used expression system due to the high amount of expressed proteins [18]. $S$. cerevisiae allows correct folding and glycosylation of heterologous eukaryotic proteins. The recombinant proteins were expressed in S. cerevisiae to a high level. Enzymes expressed in $S$. cerevisiae have a much greater molecular mass than in their natural host, due to extensive $N$-hyperglycosylation [19].

The aim of this study was cloning of $\mathrm{CHO}$ in yeast $S$. cerevisiae and $P$. pastoris, as well as its expression in these, nowadays, widely applied expression systems. We tried to obtain an enzyme that could be applied to enzymatic assays, biosensors, or as a supplement to the food industry and in the industry for bleaching detergents.

\section{MATERIAL AND METHODS}

\section{Genes for $\mathrm{CHO}$}

The synthetic gene for the $\mathrm{CHO}(1821 \mathrm{bp})$ from the L. sativa was obtained from GenScript Company, USA, and cloned into the vector pUC57.

\section{Strains and vectors}

E. coli strain $\mathrm{DH} 5 \alpha$ was used for cloning of genes and maintenance of the plasmid. $P$. pastoris, strain $\mathrm{X}-33$, and the $S$. cerevisiae strain InvSC1 were used for extracellular expression of the carbohydrate oxidase. PGAPZ $\alpha A$ vector, used for the expression of the carbohydrate oxidase in $P$. pastoris strain $\mathrm{X}-33$, as well as the expression vector pYES2 carbohydrate oxidase in $S$. 
cerevisiae strain InvSC1, were supplied by the company Invitrogen, Carlsbad, CA, USA.

\section{Media for the growth of microorganisms}

\section{Luria Broth medium (LB)}

LB medium was used for the growth of bacteria. The LB medium contained: yeast extract, $5 \mathrm{~g} \mathrm{~L}^{-1} ; \mathrm{NaCl}, 5$ $\mathrm{g} \mathrm{L}^{-1}$; tryptone, $10 \mathrm{~g} \mathrm{~L}^{-1}$; agar, $20 \mathrm{~g} \mathrm{~L}^{-1}$ (for solid medium) and antibiotics: zeocin $\left(25 \mathrm{mg} \mathrm{mL}^{-1}\right)$ or ampicillin (100 mg mL ${ }^{-1}$ ). Antibiotics have been added to the media after adjusting $\mathrm{pH}$ to 7.4 , autoclaving and cooling to $40-50{ }^{\circ} \mathrm{C}$.

\section{Liquid medium for optimal growth of the bacteria (SOC)}

SOC medium is primarily used for recovery of transformed $E$. coli competent cells. This medium improves the productivity of transformation of competent cells and contains: tryptone, $20 \mathrm{~g} \mathrm{~L}^{-1}$, yeast extract, $5 \mathrm{~g} \mathrm{~L}^{-1}$, $\mathrm{NaCl}, 0.5 \mathrm{~g} \mathrm{~L}^{-1}, 10 \mathrm{mM} \mathrm{MgCl}_{2}, 10 \mathrm{mM} \mathrm{MgSO}_{4}$, glucose, 4 $\mathrm{g} \mathrm{L}^{-1}$. The media were autoclaved prior to addition of sterile solutions of $\mathrm{MgCl}_{2}, \mathrm{MgSO}_{4}$ and glucose through filter sterilization.

\section{YPDS medium for $P$. pastoris growth}

This medium was used for growing $P$. pastoris cells after transformation. The medium contains: yeast extract $10 \mathrm{~g} \mathrm{~L}^{-1}$, peptone $20 \mathrm{~g} \mathrm{~L}^{-1}, 1 \mathrm{M}$ sorbitol, agar $20 \mathrm{~g} \mathrm{~L}^{-1}$ (for solid medium), zeocin $100 \mathrm{mg} \mathrm{mL}^{-1}$ and glucose 20 $\mathrm{g} \mathrm{L}^{-1}$. The media were adjusted to $\mathrm{pH} 7.4$ and autoclaved prior to addition of sterile solutions of glucose and zeocine through filter sterilization.

\section{Rich liquid medium for growth of yeasts (2XYPAD)}

2XYPAD is used for culture growing to log phase before transformation. The medium contains: yeast extract, $20 \mathrm{~g} \mathrm{~L}^{-1}$, peptone, $40 \mathrm{~g} \mathrm{~L}^{-1}$, adenosine sulfate, $80 \mathrm{mg} \mathrm{L}^{-1}$ and glucose, $40 \mathrm{~g} \mathrm{~L}^{-1}$.

\section{YNB-CAA medium}

YNB-CAA medium was used for the selection of transformed yeast $S$. cerevisiae and consists of: $\left(\mathrm{NH}_{4}\right)_{2} \mathrm{SO}_{4}, 5.1 \mathrm{~g} \mathrm{~L}^{-1}$, YNB (yeast nitrogen base) without amino acids and ammonium sulfate $\left(1.6 \mathrm{~g} \mathrm{~L}^{-1}\right)$, bacto casamino acid, $5 \mathrm{~g} \mathrm{~L}^{-1}$, agar, $20 \mathrm{~g} \mathrm{~L}^{-1}$ (for solid medium), adenine, $20 \mathrm{mg} \mathrm{L}^{-1}$, tryptophan, $20 \mathrm{mg} \mathrm{L}^{-1}$ and either glucose $(2 \%$, for selective media) or galactose $(2 \%$, for inducible media). Glucose or galactose have been added to the media from a sterile solution, after adjusting the $\mathrm{pH}$ to 5-6 and autoclaving.

\section{Preparation of competent cells}

\section{Preparation of chemically competent E. coli DH5 $\alpha$ cells}

A single colony of $E$. coli $\mathrm{DH} 5 \alpha$ was inoculated from a LA agar plate into $5 \mathrm{~mL}$ of LB liquid medium and grown in a shaker (250 rpm) over night at $37^{\circ} \mathrm{C} .1 \mathrm{~mL}$ of the overnight culture was transferred in $100 \mathrm{~mL}$ of LB liquid medium and cells were grown in a shaker (250 rpm) at $37{ }^{\circ} \mathrm{C}$ until the optical density reached a value between $0.3-0.5$ at $600 \mathrm{~nm}$ (about 2-3 h). When the cells have reached the appropriate optical density, they were transferred on ice for $10 \mathrm{~min}$ and then centrifuged for $5 \mathrm{~min}$ at $3000 \mathrm{rpm}$ at $4{ }^{\circ} \mathrm{C}$. The precipitate was resuspended in $10 \mathrm{~mL}$ sterile cold $\mathrm{CaCl}_{2}$ solution (60 mM CaCl $2,15 \%$ glycerol, 10 mM TRIS, pH 7.0) and incubated on ice for $30 \mathrm{~min}$. Cells were centrifuged for $5 \mathrm{~min}$ at $3000 \mathrm{rpm}$ at $4{ }^{\circ} \mathrm{C}$, then resuspended in $2 \mathrm{~mL}$ of sterile cold $\mathrm{CaCl}_{2}$ solution, aliquoted at $100 \mu \mathrm{L}$, immediately frozen in liquid nitrogen and stored at $-80{ }^{\circ} \mathrm{C}$ [20].

Preparation of electrocompetent cells of Pichia pastoris $X-33$

A single colony of $P$. pastoris $X-33$ was inoculated from YPD agar plate into $3 \mathrm{~mL}$ of YPD liquid medium containing $12.5 \mu \mathrm{g} / \mathrm{mL}$ chloramphenicol and grown in a shaker $(250 \mathrm{rpm})$ over night at $30{ }^{\circ} \mathrm{C}$. The overnight culture was transferred into $50 \mathrm{~mL}$ of YPD medium and the optical density was measured at $600 \mathrm{~nm}$. Cells were grown in a shaker $(250 \mathrm{rpm})$ at $30{ }^{\circ} \mathrm{C}$ until the optical density increased to $1-2$. After reaching the appropriate optical density, cells were centrifuged for $10 \mathrm{~min}$ at $3000 \mathrm{rpm}$, resuspended in $10 \mathrm{~mL}$ of DTT/LiAc solution, and incubated for $30 \mathrm{~min}$ at room temperature. Then the cells were centrifuged again for $5 \mathrm{~min}$ at 3000 rpm, resuspended in $1 \mathrm{~mL}$ of cold $1 \mathrm{M}$ sorbitol, transferred to a mini tube $(1.5 \mathrm{~mL})$ and centrifuged $5 \mathrm{~min}$ at $5000 \mathrm{rpm} / \mathrm{min}$. The cells were then washed three times in cold $1 \mathrm{M}$ sorbitol, resuspended in $500 \mu$ of cold $1 \mathrm{M}$ sorbitol and frozen at $-80^{\circ} \mathrm{C}$.

\section{Preparation of competent S. cerevisiae cells InvSC1}

A single colony of S.cerevisiae InvSC1 was inoculated from YPD agar plate into $2.5 \mathrm{~mL}$ 2xYPAD liquid media containing $12.5 \mu \mathrm{g} / \mathrm{mL}$ chloramphenicol and grown in a shaker $(250 \mathrm{rpm})$ over night at $30{ }^{\circ} \mathrm{C}$. The overnight culture was transferred to $50 \mathrm{~mL}$ of 2xYPAD medium and the optical density was measured at 600 $\mathrm{nm}$. Cells were grown in a shaker $(250 \mathrm{rpm})$ at $30{ }^{\circ} \mathrm{C}$ until the optical density increased 4 times (about $4 \mathrm{~h}$ ). After the cells have reached the appropriate optical density, they were centrifuged for $5 \mathrm{~min}$ at $3000 \mathrm{rpm}$, resuspended in $25 \mathrm{~mL}$ of sterile water and then centrifuged again for $5 \mathrm{~min}$ at $3000 \mathrm{rpm}$. After that, cells were resuspended in $500 \mu \mathrm{l}$ of sterile water, centrifuged for $5 \mathrm{~min}$ at $6000 \mathrm{rpm}$, resuspended in $500 \mu \mathrm{l}$ of a sterile solution of the FCC ( $5 \%$ glycerol, $10 \%$ DMSO) and frozen at $-80^{\circ} \mathrm{C}$.

\section{Cloning of $\mathrm{CHO}$}

\section{Cloning of $\mathrm{CHO}$ in $P G A P Z \alpha A$ vector}

Restriction of $\mathrm{CHO}-p \cup C$ and $p G A P Z \alpha A$ vectors. $\mathrm{CHO}$ -pUC57 was checked for restriction before cloning into the vector pGAPZ $\alpha$ A EcoRI. CHO-pUC and pGAPZ $\alpha A$ 
vector were subjected to a double restriction with enzymes Xbal and Xhol. Restriction mixture contained components shown in Table 1.

Table 1. Components for restriction mixture for $\mathrm{CHO}-\mathrm{pUC}$ and $p G A P Z \alpha A$ vector double restriction with enzymes $\mathrm{Xbal}$ and Xhol

\begin{tabular}{lcc}
\hline Component & CHO-pUC & pGAPZ $\alpha$ A vector $(\mu \mathrm{L})$ \\
\hline 10x Tango buffer & 4 & 4 \\
$\begin{array}{l}\text { Xhol resriction enzyme } \\
(10 \mathrm{U} / \mu \mathrm{L})\end{array}$ & 2 & 2 \\
Xbal resriction enzyme & 1 & 1 \\
$(10 \mathrm{U} / \mu \mathrm{L})$ & & \\
Plasmid & 10 & 10 \\
MiliQ water & 3 & 3 \\
Total volume, $\mathrm{mL}$ & 20 & 20 \\
\hline
\end{tabular}

Restriction mixture was incubated for $16 \mathrm{~h}$ at $37^{\circ} \mathrm{C}$. After $16 \mathrm{~h}$ the reaction was stopped by incubating for $20 \mathrm{~min}$ at $80{ }^{\circ} \mathrm{C}$. The digested $p G A P Z \alpha A$ vector was purified with GeneJet PCR Purification Kit (Fermentas, Canada). Digested CHO-pUC was subjected to dephosphorylation. Mixture of dephosphorylation contained: $2 \mu \mathrm{L} 10 \mathrm{x}$ buffer for alkaline phosphatase, $0.5 \mu \mathrm{L}$ alcaline phosphatase $(1 \mathrm{U} / \mu \mathrm{L}), 15 \mu \mathrm{L}$ of sample and $2.5 \mu \mathrm{L}$ MiliQ water. Total volume of the reaction mixture was $20 \mu \mathrm{L}$.

The mixture was incubated at $37{ }^{\circ} \mathrm{C}$ for $10 \mathrm{~min}$ and after that at $75{ }^{\circ} \mathrm{C}$. After dephosphorylation and purification of restricted CHO-pUC and pGAPZ $\alpha A$ vectors, the samples were checked by agarose electrophoresis.

Ligation of $\mathrm{CHO}$ pGAPZ $\alpha A$ vectors and transformation of $E$. coli $\mathrm{DH} 5 \alpha$

After the successful restriction of $\mathrm{CHO}-p U \mathrm{C}$ and pGAPZ $\alpha A$ vectors, the gene for $\mathrm{CHO}$ was ligated into the $p G A P Z \alpha A$ vector. Ligation mixture contained: $2 \mu \mathrm{L}$ 10x T4 buffer for ligation, $0.5 \mu \mathrm{L}$ ligase $(10 \mathrm{U} / \mu \mathrm{L}), 3 \mu \mathrm{L}$ dephosphorilated $\mathrm{CHO}(12 \mathrm{ng} / \mu \mathrm{L}), 10 \mu \mathrm{L}$ pGAPZ $\alpha \mathrm{A}(1$ $\mathrm{ng} / \mu \mathrm{L}), 4.5 \mu \mathrm{L}$ MiliQ water. Total volume of the reaction mixture was $20 \mu \mathrm{L}$.

Ligation mixture was incubated for $16 \mathrm{~h}$ at $16{ }^{\circ} \mathrm{C}$, and then at $70{ }^{\circ} \mathrm{C}$ for $5 \mathrm{~min} .2 \mu \mathrm{L}$ of this mixture was added to $100 \mu \mathrm{L}$ of frozen electrocompetent $E$. coli $\mathrm{DH} 5 \alpha$ cells. The entire mixture was then transferred to a cold cuvette (which was pre-incubated on ice for 5 min) for transformation. The mixture was incubated on ice in cuvettes for $1 \mathrm{~min}$. $1 \mathrm{~mL}$ of SOC medium was added and the mixture was transferred to a sterile tube and incubated for $1 \mathrm{~h}$ at $37^{\circ} \mathrm{C}(250 \mathrm{rpm})$.

After $1 \mathrm{~h} 200 \mu \mathrm{L}$ of transformation mixture was plated on solid LB medium with zeocin. The plates were incubated overnight at $37{ }^{\circ} \mathrm{C}$. The next day, colonies were transferred to a fresh solid LB medium with zeocin and individually placed in $1 \mathrm{~mL}$ of liquid LB medium with zeocin. Liquid cultures were incubated overnight at $37{ }^{\circ} \mathrm{C}$ and $250 \mathrm{rpm}$. After two days, plasmids were isolated from the growing colonies. Before transformation of $P$. pastoris $\mathrm{X}-33$, linearized plasmids were isolated. The mixture for linearization contained: $2 \mu \mathrm{L} 10 \mathrm{x}$ Tango buffer, $0.5 \mu \mathrm{L}$ Xmajl restricted enzyme (10 U/ $\mu \mathrm{L})$, $1 \mu \mathrm{L} \mathrm{CHO-pGAP}$ and $16.5 \mu \mathrm{L}$ MiliQ water. Total volume of the reaction mixture was $20 \mu \mathrm{L}$. The mixture was incubated for $12 \mathrm{~h}$ at $37{ }^{\circ} \mathrm{C}$ and then at $80{ }^{\circ} \mathrm{C}$ for 20 min. Linearized plasmids were tested by agarose electrophoresis.

\section{Transformation of $P$. pastoris $X-33$}

Cuvettes for the transformation were pre-incubated on ice for $5 \mathrm{~min} .10 \mu \mathrm{L}$ of linearized plasmid was added to $100 \mu \mathrm{L}$ of competent cells. The mixture was supplemented with $1 \mathrm{~mL}$ of sterile sorbitol, transferred to a sterile tube and incubated for $1 \mathrm{~h}$ at $30{ }^{\circ} \mathrm{C}$ without mixing. After $1 \mathrm{~h}, 500 \mu \mathrm{l}$ of YPD medium was added and the mixture was incubated for $3 \mathrm{~h}$ at $30{ }^{\circ} \mathrm{C}, 250 \mathrm{rpm}$. After $3 \mathrm{~h}, 200 \mu \mathrm{L}$ of transformation mixture was transferred to solid YPDS medium with zeocin at a final concentration of $100 \mathrm{mg} / \mathrm{mL}$.

\section{Cloning of carbohydrate oxidase into the pYES2 vector}

Restriction of CHO-pUC and pYES2 vectors. CHO-pUC57 and pYES2 vectors were subjected to double digestion in the presence of $\mathrm{Xbal}$ and EcoRI restriction enzymes. Restriction mixture contained components shown in Table 2.

Table 2. Components for restriction mixture for $\mathrm{CHO}-\mathrm{pUC57}$ and pYES2 vector double restriction with enzymes $\mathrm{Xbal}$ and Xhol

\begin{tabular}{lcc}
\hline Component & CHO-pUC57 $(\mu \mathrm{L})$ & pYES2 vector $(\mu \mathrm{L})$ \\
\hline 10xTango buffer & 4 & 4 \\
EcoRI $(10 \mathrm{U} / \mu \mathrm{L})$ & 1 & 1 \\
Xbal $(10 \mathrm{U} / \mu \mathrm{L})$ & 2 & 2 \\
Plasmid & 6 & 13 \\
MiliQ water & 7 & 0 \\
Total volume & 20 & 20 \\
\hline
\end{tabular}

Restriction mixtures were incubated at $37{ }^{\circ} \mathrm{C}$ overnight and then at $80{ }^{\circ} \mathrm{C}$ for $20 \mathrm{~min}$. Digested $\mathrm{CHO}-$ -pUC57 was subjected to dephosphorylation, in a mixture containing: $2 \mu \mathrm{L} 10 \mathrm{x}$ buffer for alcaline phosphatase, $1 \mu \mathrm{L}$ alcaline phosphatase, $15 \mu \mathrm{L}$ sample and $2 \mu \mathrm{L}$ MiliQ water. Total volume of reaction mixture was 20 $\mu \mathrm{L}$. The reaction was running for $10 \mathrm{~min}$ at $37^{\circ} \mathrm{C}$, followed by $5 \mathrm{~min}$ at $75^{\circ} \mathrm{C}$. After double digestion with GeneJet PCR Purification Kit (Fermentas, Canada), pYES2 was purified and then checked by agarose electrophoresis.

Ligation of $C H O$ and $p Y E S 2$ and transformation of E. coli $D H 5 \alpha$

After the successful restriction of $\mathrm{CHO}-\mathrm{pUC}$ and pYES2 vector, the $\mathrm{CHO}$ gene was ligated into the vector 
pYES2. The ligation mixture contained: $2 \mu$ L10x T4 ligation buffer, $0.5 \mu \mathrm{L}$ ligase $(10 \mathrm{U} / \mu \mathrm{L}), 1 \mu \mathrm{L}$ dephosphorilated $\mathrm{CHO}(65 \mathrm{ng} / \mu \mathrm{L}), 10 \mu \mathrm{L}$ pYES2 $(2 \mathrm{ng} / \mu \mathrm{L}), 6.5 \mu \mathrm{L}$ MiliQ water. Total volume of reaction mixture was 20 $\mu \mathrm{L}$.

Ligation mixture was incubated for $16 \mathrm{~h}$ at $16{ }^{\circ} \mathrm{C}$, followed by $10 \mathrm{~min}$ at $70{ }^{\circ} \mathrm{C} .2 \mu \mathrm{L}$ of this mixture was added into $100 \mu \mathrm{L}$ frozen electrocompetent $E$. coli DH5 $\alpha$ cells. The mixture was incubated on ice cuvettes for $1 \mathrm{~min} .1 \mathrm{~mL}$ of SOC medium was added and the mixture was transferred to a sterile tube and incubated for $1 \mathrm{~h}$ at $37^{\circ} \mathrm{C}(250 \mathrm{rpm})$.

After $1 \mathrm{~h} 200 \mu \mathrm{L}$ of transformation mixture was plated on solid LB medium with ampicillin. The plates were incubated overnight at $37{ }^{\circ} \mathrm{C}$. The next day growing colonies were tranferred on a fresh solid LB medium with ampicillin. Liquid cultures were incubated overnight at $37^{\circ} \mathrm{C}$ and $250 \mathrm{rpm}$. The next day, plasmids were isolated from growing colonies and then checked with EcoRI restriction. Restriction mixture was incubated for $3 \mathrm{~h}$ at $37{ }^{\circ} \mathrm{C}$, and contained: $1 \mu \mathrm{L} 10 x E c o R I$ buffer, $0.5 \mu \mathrm{L}$ EcoRI $(10 \mathrm{U} / \mu \mathrm{L}), 4 \mu \mathrm{L}$ plasmid and $4.5 \mu \mathrm{L}$ MiliQ water. Total volume of the reaction mixture was $10 \mu \mathrm{L}$

Three of the constructs displayed the bands corresponding to the expected molecular mass. To determine if constructs have the gene for $\mathrm{CHOx}$ inserted into PYES2 expression vector, another double digestion with EcoRI and Xbal enzymes was performed. The reaction mixture contained: $4 \mu \mathrm{L}$ 10x Tango buffer, $1 \mu \mathrm{L}$ EcoRI (10 U/ $\mu \mathrm{L}), 2 \mu \mathrm{L}$ Xbal $(10 \mathrm{U} / \mu \mathrm{L}), 5 \mu \mathrm{L}$ plasmid and $8 \mu \mathrm{L}$ MiliQ water. Total volume of the reaction mixture was $20 \mu \mathrm{L}$. The mixture was incubated for $3 \mathrm{~h}$ at $37^{\circ} \mathrm{C}$, then $20 \mathrm{~min}$ at $80^{\circ} \mathrm{C}$ and DNA was analyzed by agarose electrophoresis.

\section{Transformation of S. cerevisiae InvSC1}

Chemically competent cells InvSC1 were centrifuged for $2 \mathrm{~min}$ at $13000 \mathrm{rpm}$. Then the cells were transferred to a solution containing $260 \mu \mathrm{L}$ of PEG, $36 \mu \mathrm{L}$ Li acetate, $50 \mu \mathrm{L}$ SS DNA (which was previously heated for $5 \mathrm{~min}$ at $100{ }^{\circ} \mathrm{C}$ ) and $14 \mu \mathrm{L}$ of the plasmid. The mixture was vortexed and incubated for $1 \mathrm{~h}$ at $42{ }^{\circ} \mathrm{C}$, with occasional mixing. $1 \mathrm{~mL}$ YNB-CAA-Glc-A-T was added to the mixture. Plates with cells were incubated for 2 days at $30^{\circ} \mathrm{C}$.

\section{Isolation of plasmid}

A single colony from the LA medium supplemented with antibiotics was inoculated into $3 \mathrm{~mL}$ of medium and grown in a shaker (250 revolutions/min) at $37^{\circ} \mathrm{C}$ overnight. The culture was transferred to a $1.5 \mathrm{~mL}$ eppendorf tube and centrifuged for $1 \mathrm{~min}$ at 13000 rpm. The supernatant was removed and the cells were resuspended in $150 \mu \mathrm{L}$ of cold GTE+ solution $(25 \mathrm{mM}$ TRIS, $10 \mathrm{mM}$ EDTA, $50 \mathrm{mM}$ glucose, $100 \mathrm{mg} / \mathrm{mL}$ of ribonuclease, $\mathrm{pH} 8.0)+300 \mu \mathrm{L}$ of freshly prepared $\mathrm{P} 2$ solution (200 mM NaOH, 1\% SDS) and slowly mixed until the solution became clear. After that $450 \mu \mathrm{L}$ of cold potassium acetate solution ( $4 \mathrm{M} \mathrm{CH}_{3} \mathrm{COOK}, \mathrm{pH}$ 6.3) was added and slowly mixed. The suspension was centrifuged for $4 \mathrm{~min}$ at $13000 \mathrm{rpm}$. The supernatant was transferred to a new eppendorf tube with $400 \mu \mathrm{L}$ isopropanol. The content was mixed several times and centrifuged for $4 \mathrm{~min}$ at $13000 \mathrm{rpm}$. The supernatant was removed and $1 \mathrm{~mL}$ of ice-cold $75 \%$ ethanol was added to the residue. The solution was centrifuged for $2 \mathrm{~min}$ at $13000 \mathrm{rpm}$. The supernatant was removed and the precipitate (plasmid DNA) was dried in a vacuum evaporator.

\section{Yeast fermentation}

Production of carbohydrate oxidase in P. pastoris $X-33$

Colonies, which grew after transformation of $P$. pastoris on YPDS medium containing zeocin, were plated in $1 \mathrm{~mL}$ of YPD medium with zeocin and incubated for two days at $30{ }^{\circ} \mathrm{C}$ and $250 \mathrm{rpm}$. After two days, the colonies were tested under the microscope, in order to determine contamination. Non-contaminated colonies were tested in the ABTS assay for detection of carbohydrate oxidase activity. As none of the colonies showed $\mathrm{CHO}$ activity, all were centrifuged and dissolved respectively in $0.1 \mathrm{M}$ sodium acetate buffer $\mathrm{pH} 5.5$ and then tested with SDS PAGE.

After silver staining, seven colonies were selected which were re-tested in SDS PAGE after precipitation of trichloroacetic acid (TCA). Three of these colonies were placed into $10 \mathrm{~mL}$ YPD medium with zeocin, in a final concentration of $100 \mathrm{mg} / \mathrm{mL}$. The colonies were incubated at $30{ }^{\circ} \mathrm{C}$ and $250 \mathrm{rpm}$ for 4 days.

After fermentation, all samples were TCA precipitated and then tested on SDS PAGE. The samples were tested with native PAGE and zymogram.

\section{Production of carbohydrate oxidase in S. cerevisiae InvSC1}

Colonies were grown after $24 \mathrm{~h}$ on YNB + CAA-Glc + $\mathrm{T}+\mathrm{A}$ solid medium, inoculated with $1 \mathrm{~mL}$ of the same liquid medium and incubated for $24 \mathrm{~h}$ at $30^{\circ} \mathrm{C}$ and 25 rpm. After $24 \mathrm{~h}, 3 \mathrm{~mL}$ of the liquid YNB + CAA-Gal + A + $T$ medium was added to each of the colonies and they were incubated at $30{ }^{\circ} \mathrm{C}$ and $250 \mathrm{rpm}$ for $12 \mathrm{~h}$, after which the colonies were concentrated from 100 to 10 $\mathrm{mL}$ by ultrafiltration on a membrane of $50 \mathrm{kDa}$. Finally, samples were tested on SDS PAGE.

\section{Determination and expression of $\mathrm{CHO}$}

\section{ABTS assay}

The mixtures for determining the activity of glucose oxidase contained $60 \mathrm{mM}$ sodium acetate buffer $\mathrm{pH}$ 5.5, $333 \mathrm{mM}$ glucose, $1 \mathrm{mM}$ ABTS, $1 \mathrm{U} / \mathrm{mL} \mathrm{HRP}$ in a volume of $990 \mu \mathrm{L}$. Change in absorbance was measured 
at $405 \mathrm{~nm}$ after addition of $10 \mu \mathrm{L}$ of sample with carbohydrate oxidase. $1 \mathrm{U}$ of $\mathrm{CHO}$ is defined as the quantity of the enzyme producing $1 \mu \mathrm{mol}$ hydrogen peroxide in $1 \mathrm{~min}$. The amount of hydrogen peroxide was determined by the concentration of the oxidized ABTS whose extinction coefficient at $405 \mathrm{~nm}$ is $36.8 \mathrm{~mL} \mathrm{\mu mol}^{-1} \mathrm{~cm}^{-1}$ [21].

\section{Precipitation of the protein with TCA}

TCA precipitation of the proteins was performed in cold conditions. $250 \mu \mathrm{L}$ TCA (50\% TCA in dH2O) was added into $500 \mu \mathrm{l}$ of sample. The tubes were vortexed and centrifuged for $10 \mathrm{~min}$ at $4{ }^{\circ} \mathrm{C}$. The supernatant was removed and sample was mixed with $200 \mu \mathrm{L}$ acetone. After another centrifugation, the supernatant was again removed, and the side walls of the tube were washed with another $100 \mu \mathrm{L}$ of acetone. The supernatant was removed and the sample was dried at room temperature. The sample was resuspended in a small volume of the $0.1 \mathrm{M}$ sodium acetate buffer $\mathrm{pH}$ 5.5.

\section{Electrophoretic techniques}

\section{DNA agarose electrophoresis}

For DNA agarose electrophoresis, 1\% agarose in TBE buffer ( $89 \mathrm{mM}$ TRIS, $89 \mathrm{mM}$ boric acid, $20 \mathrm{mM}$ EDTA, $\mathrm{pH}$ 8.0) was used and $5 \mu \mathrm{L}$ of DNA sample was mixed with the color in 1:5 proportion. DNA markers for electrophoresis (Fermentas, Canada) were applied in an amount of $3 \mu \mathrm{L}$. Electrophoresis started at a voltage of $80 \mathrm{~V}$ until the dye reached the end of the gel. After completion of electrophoresis, the gel was immersed for $5 \mathrm{~min}$ in a solution of ethidium bromide $0.5 \mathrm{mg} / \mathrm{mL}$ and filmed under UV light.

\section{SDS polyacrylamide gel electrophoresis (SDS PAGE)}

For the analysis of glucose oxidase, the reductive polyacrylamide electrophoresis was used [22]. The gels contained the components as shown in Table 3.

Table 3. The gels for SDS-PAGE

\begin{tabular}{lcc}
\hline Solutions & $\begin{array}{c}8 \% \text { Separating } \\
\text { gel }\end{array}$ & $\begin{array}{c}4 \% \text { Gel for } \\
\text { concentration }\end{array}$ \\
\hline Acrylamide monomer solution & $3,33 \mathrm{~mL}$ & $0,50 \mathrm{~mL}$ \\
$(30 \% \mathrm{~T}, 2,7 \% \mathrm{C})$ & & \\
$1.5 \mathrm{M} \mathrm{TRIS} \mathrm{pH} 8,8$ & $2,50 \mathrm{~mL}$ & - \\
$0.5 \mathrm{M}$ TRIS pH 6,8 & - & $0,94 \mathrm{~mL}$ \\
Water & $4 \mathrm{~mL}$ & $2,25 \mathrm{~mL}$ \\
$10 \%$ SDS & $0,10 \mathrm{~mL}$ & $38 \mathrm{~mL}$ \\
TEMED & $4 \mu \mathrm{L}$ & $2 \mu \mathrm{L}$ \\
$10 \%$ Ammonium persulfate (APS) & $50 \mu \mathrm{L}$ & $25 \mu \mathrm{L}$ \\
Total volume & $10 \mathrm{~mL}$ & $4 \mathrm{~mL}$ \\
\hline
\end{tabular}

Samples for SDS electrophoresis were mixed with preparation buffer (60 mM TRIS pH 6.8, 25\% glycerol, 2\% SDS, $14.4 \mathrm{mM} \beta$-mercaptoethanol, 0.1\% bromo- phenol blue) at a ratio of $1: 4$. The resulting solution was boiled for $5 \mathrm{~min}$ at $95{ }^{\circ} \mathrm{C}$. Protein markers for electrophoresis (Fermentas, Canada) were applied in 5 $\mu \mathrm{L}$ volume.

Electrophoresis was done for $2 \mathrm{~h}$ at constant voltage of $150 \mathrm{~V}$ in a water bath containing electrophoresis buffer (0.025 M Tris pH 8.3, $0.192 \mathrm{M}$ glycine, 0.1\% SDS). Electrophoresis was stopped when bromophenol blue dye reached the edge of the gel. The gel was fixed and stained with CBB (Coomassie brilliant blue) G-250 (0.1\% CBB and 50\% methanol, 10\% acetic acid) overnight. Bleaching of the gel was carried out in $7 \%$ acetic acid solution until the appearance of stained protein bands on the gel.

\section{Native gel electrophoresis}

Solutions for native electrophoresis were identical to solutions for SDS-PAGE electrophoresis, except that no SDS was added to the gel and no $\beta$-mercaptoethanol was added to the buffer. Electrophoresis was done in the same order as in the SDS-PAGE electrophoresis. After completion of the electrophoresis gel was colored with silver. The protocol for the silver staining of gel is given in the Table 4.

Table 4. The protocol for the silver staining of gel

\begin{tabular}{lc}
\hline Solution & Time, min \\
\hline 1. Rinse with dH2O & 1 \\
2. $50 \%$ methanol, $20 \%$ TCA, $2 \%$ & 15 \\
$\mathrm{CuCl}_{2}$ & 10 \\
3. $10 \%$ ethanol, $5 \%$ acetic acid & 10 \\
4. $0.01 \% \mathrm{KMnO}_{4}$ & 1 \\
5. Rinse $2 \times$ with $\mathrm{dH}_{2} \mathrm{O}$ & 10 \\
6. $10 \%$ ethanol, $5 \%$ acetic acid & 10 \\
7. $10 \%$ ethanol & 1 \\
8. Rinse $2 \times$ with $\mathrm{dH}_{2} \mathrm{O}$ & 10 \\
9. dist. $\mathrm{H}_{2} \mathrm{O}$ & 10 \\
10. $0,1 \% \mathrm{AgNO}_{3}$ & 20 sec \\
11. Rinse with dist. $\mathrm{H}_{2} \mathrm{O}$ & 1 \\
12. $10 \% \mathrm{~K}_{2} \mathrm{CO}_{3}$ & Untill the occurrence of strip \\
13. $2 \% \mathrm{~K}_{2} \mathrm{CO}_{3}, 0.01 \%$ & 20 sec \\
formaldehyde & 20 sec \\
14. $10 \%$ ethanol, $5 \%$ acetic acid & Unlimited \\
15. Rinse with dist. $\mathrm{H}_{2} \mathrm{O}$ & \\
16. Stain in $0,02 \% \mathrm{~K}_{2} \mathrm{CO}_{3}$ &
\end{tabular}

\section{Zymogram}

Zymogram was done identically to the native electrophoresis, only that instead of washing the gel with distilled water, the gel was dipped in the solution for activity determination. In contrast to the assay used to determine the activity of the solution, guaiacol was used instead of ABTS. 


\section{RESULTS AND DISCUSSION}

The transformation of the bacteria and miniprep with the restriction mapping of the plasmid

After double digestion of CHO-pUC57 and pGAPZ $\alpha A$ with restriction enzymes $\mathrm{Xhol}$ and $\mathrm{Xbal}, \mathrm{pGAPZ} \alpha \mathrm{A}$ vector was purified and each sample was checked on agarose gel electrophoresis to determine an approximate concentration of DNA (Fig. 1).

Comparing bands intensity of the digested samples with bands intensity of the molecular markers and quantities of DNA in each lane, the concentration of pGAPZ $\alpha A$ was determined as $1 \mathrm{ng} / \mu \mathrm{L}$, while the concentration of digested CHO-pUC57 was $12 \mathrm{ng} / \mu \mathrm{L}$.

Six colonies grew the next day and they were transferred to a fresh solid LB medium with zeocin. Liquid cultures were incubated overnight at $37{ }^{\circ} \mathrm{C}$ and 250 rpm. After two days, the colonies 3 and 6 grew and plasmids were isolated from them. Before transformation of $P$. pastoris X-33, isolated plasmids were linearized (Fig. 2). Agarose electrophoresis of DNA showed that plasmids satisfied criteria of molecular weight (4.9 $\mathrm{kbp})$, and these plasmids were used for further transformation of $P$. pastoris X-33.

\section{Transformation of $E$. coli DH5 $\alpha$ with gene $\mathrm{CHOx}$ cloned into an expression vector $\mathrm{PYES} 2$}

After double digestion of CHO-pUC57 and pYES2 with restriction enzymes $\mathrm{EcoRI}$ and $\mathrm{Xbal}$, samples were checked by agarose gel electrophoresis in order to determine the approximate concentration of DNA (Fig. 3).

Comparing the intensity of the bands of the digested samples to the intensity of the bands corres- ponding to molecular markers and quantities of DNA in each lane, the concentration of $\mathrm{CHO}-$ pUC57 was determined as approximately $65 \mathrm{ng} / \mu \mathrm{L}$. The pYES2 plasmid was then purified and then checked by agarose gel electrophoresis (Fig. 4). Based on the intensity of molecular markers and quantities of DNA in each lane, it was determined that a concentration of pYES2 was approximately $2 \mathrm{mg} / \mu \mathrm{L}$.

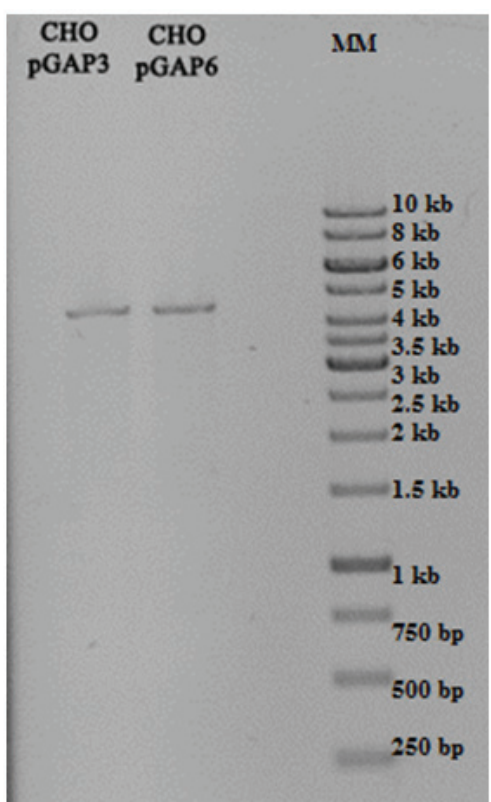

Fig. 2. DNA electrophoresis of linearized CHO-pGAP plasmids 3 and 6.

After dephosphorylation CHO-pUC57 the volume of reactants for ligation was calculated. Colonies that have
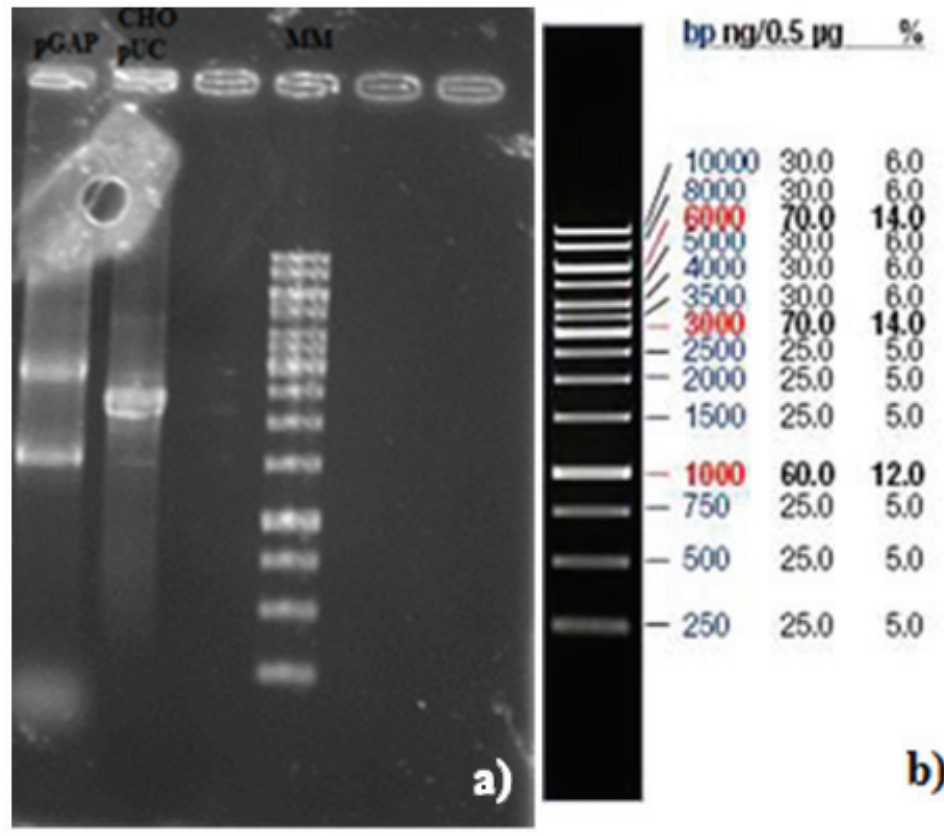

Fig. 1. DNA electrophoresis: a) digested $p G A P Z \alpha A$ and CHO-pUC57; b) DNA molecular markers. 
grown until the next day and plasmids were isolated from colonies that grew and then checked with EcoRI restriction (Fig. 5).

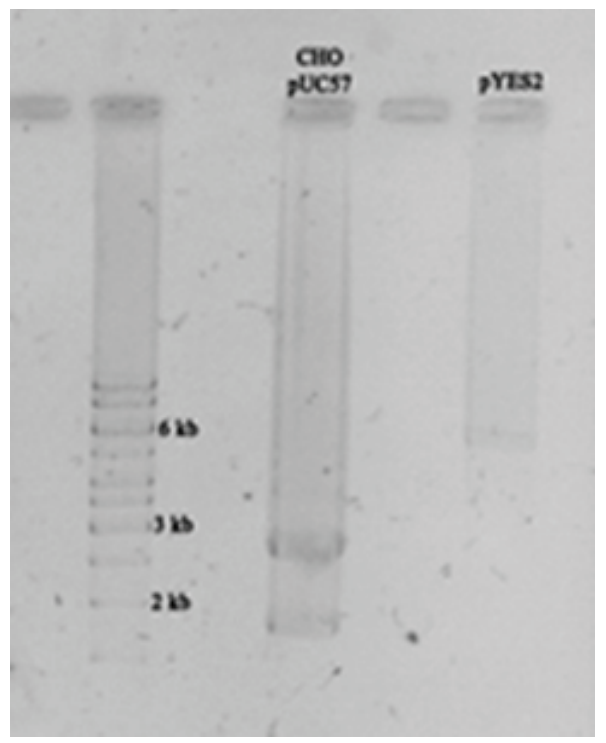

Fig. 3. DNA electrophoresis: digested pYES2 and CHO-pUC57.

The obtained results showed that constructs 14 and 15 displayed the expected size $\sim 8 \mathrm{~kb}(5.9 \mathrm{~kb}+1.8 \mathrm{~kb})$. However, the construct number 8 also showed a band of slightly below $8 \mathrm{~kb}$. Thus, the constructs 8,14 and 15 were subjected to double digestion with EcoRI and Xbal restriction enzymes for further verification (Fig. 6).

DNA electrophoresis showed that the construct 8 does not display a band on $1.8 \mathrm{~kb}$, which is the approximate length of $\mathrm{CHO}$ genes, while constructs 14 and 15 displayed two bands, corresponding to 1.8 and $5.9 \mathrm{~kb}$. These constructs were used for the further transformation of $S$. cerevisiae InvSC1.

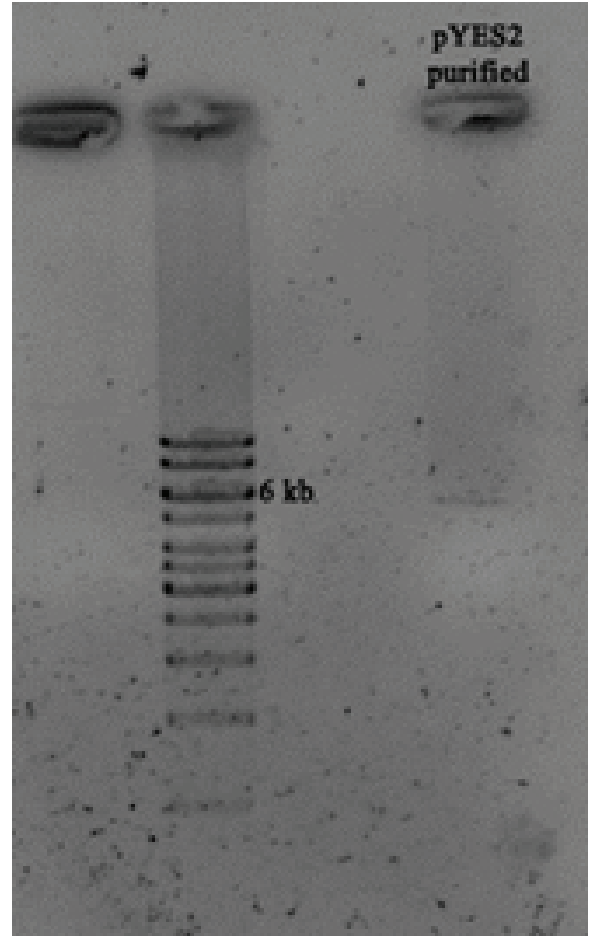

Fig. 4. DNA electrophoresis pYES2 after double digestion and purification.

\section{Transformation of yeast and fermentation}

\section{Transformation of $P$. pastoris X-33 with pGAP-CHO} construct

P. pastoris X-33 was transformed with linearized constructs 3 and 6 . Twenty five colonies of cells transformed with the construct 3 grew on a solid YPDS medium with zeocin, while 11 colonies grew on a plate with cells transformed with the construct 6 . After two days, colonies were tested under the microscope in order to determine the contamination. Colonies that were not contaminated were tested with the ABTS assay for detection of carbohydrate oxidase activity.

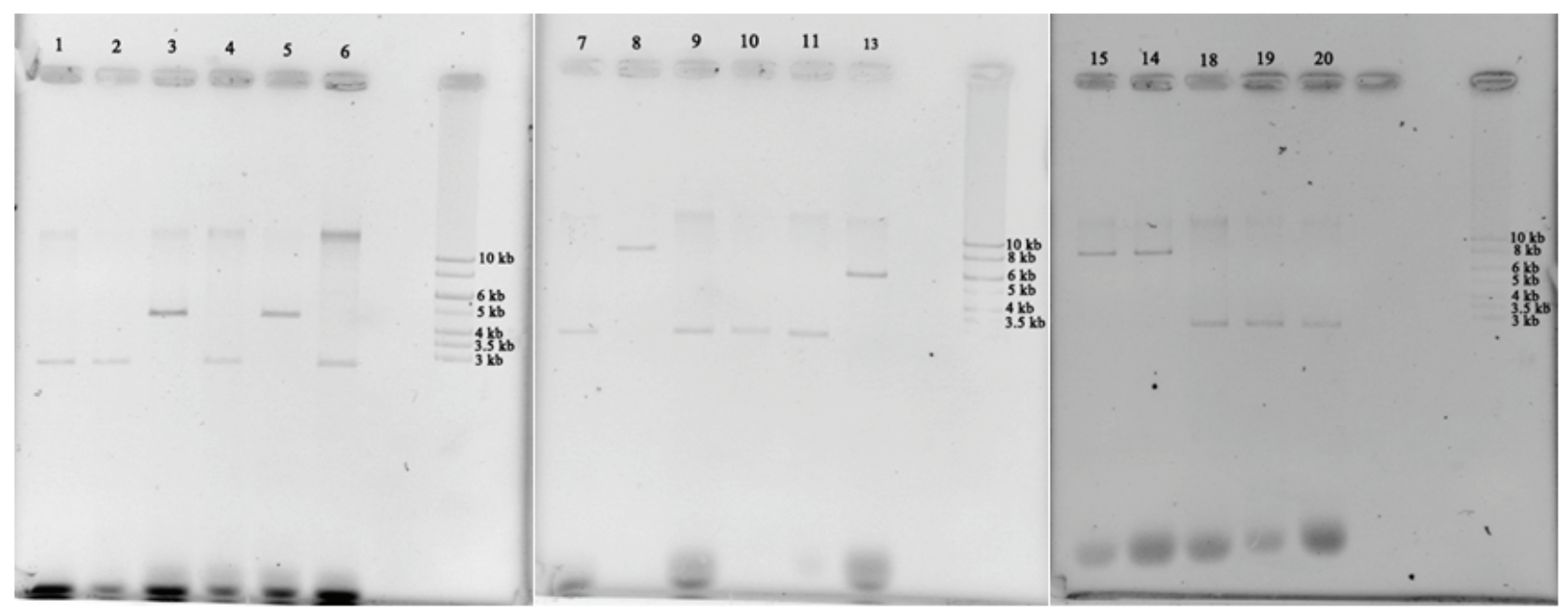

Fig. 5. DNA Electrophoresis of digested (EcoRI) constructs CHO-pYES. 
None of the colonies showed activity and all were centrifuged and resuspended in $0.1 \mathrm{M}$ sodium acetate buffer $\mathrm{pH}$ 5.5.

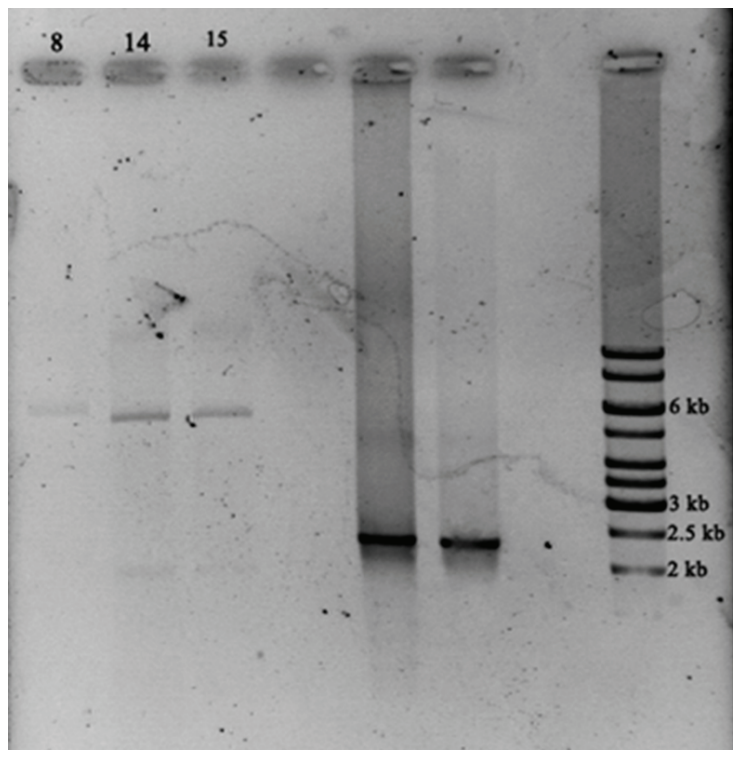

Fig. 6. DNA electrophoresis of CHO-pYES constructs with a number 8,14 and 15.

Non-contaminated colonies were tested by SDS PAGE after the first fermentation. After electrophoresis, 4 selected samples $(7,14,24$ and 26$)$ were precipitated with trichloroacetic acid (TCA) and tested by SDS PAGE (Fig. 7).

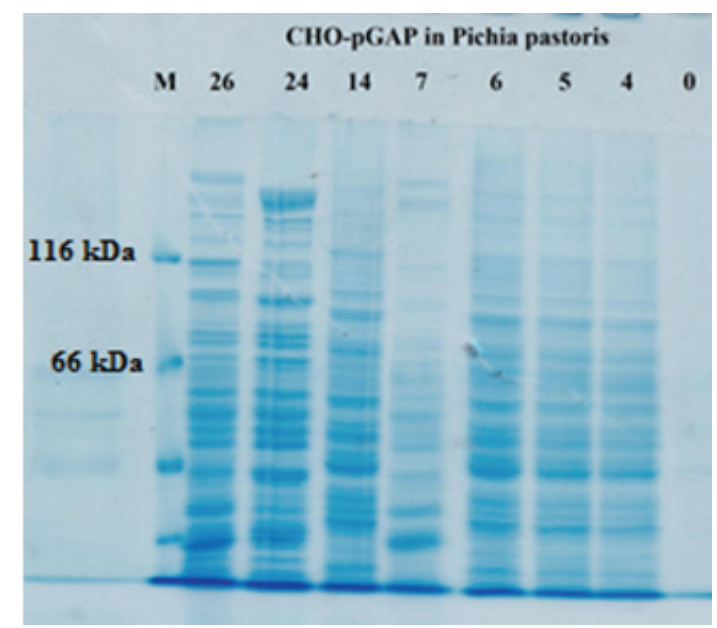

Fig. 7. SDS PAGE after TCA precipitation for 4 samples (7, 14, 24 and 26).

Based on these results, the samples with numbers 14, 24 and 26 were selected for monitoring the fermentation and time profile of the protein expression. These samples were selected because their protein bands on the electrophoresis were different from the others and from the empty pGAP (number 0). Three selected colonies were placed into $10 \mathrm{~mL}$ YPD medium with zeocin $\left(100 \mathrm{mg} \mathrm{mL}^{-1}\right)$. The colonies were incubated at $30{ }^{\circ} \mathrm{C}$ and $250 \mathrm{rpm}$ for 4 days. Aliquots were collected every 24 hours. After the fermentation, cells were centrifuged and the supernatants were precipitated with TCA again and tested on SDS PAGE (Fig. 8).

After the first day, the samples 24 and 26 displayed a band which did not occur in the sample derived from the empty vector, thus it is possible to assume that this band corresponded to the desired $\mathrm{CHO}$. The band occurred on a molecular weight higher than the theoretical molecular weight of this enzyme (greater than $120 \mathrm{kDa}$ ), but since the enzyme can be glycosylated, it could have a higher molecular weight than its expected value. Samples from the first and second day were tested with native electrophoresis, and then with zymogram with guaiacol, hoping to detect $\mathrm{CHO}$ activity which has not been detected previously with the enzyme assay. However, even these tests did not yield positive results. Foumani et al. [8] claimed that GOOX from Acremonium strictum could have a novel substrate specificity and that occurred likely due to amino acid substitution in this enzyme. Most substitutions are located on the protein surface or far from the oxidation site, which may be a reason for the lack of the enzyme activity.

There is a possibility that the enzyme had misfolded upon synthesis, so refolding it might have resulted in recovering the activity. For $P$. pastoris, the oligosaccharide chains attached to proteins are shorter and more authentic than in $S$. cerevisiae. The average chain lenght of glycoproteins expressed by $P$. pastoris is only 8-14 mannose residues, whereas that by $S$. cerevisiae it is $40-150$ residues [23]. Analysis of the carbohydrates coupled to recombinant enzymes indicated the predominant presence of $\mathrm{N}$-linked, high mannose structure and Asn-X-Ser/Thr was found to be the site of glycolisation, same as that in mammalian cells [24]. Many glycosylated proteins have been expressed successfully in P. pastoris. Up to now, many heterologous proteins have been expressed in $P$. pastoris because the level of expression is equivalent to that of $E$. coli and significantly higher than that of S. cerevisiae [25]. Expression and secretion of these heterologous proteins, however, depends not only on gene dosage, but also on other factors, such as signal sequence recognition and processing, proteolysis, fermentation and glycosylation.

Salts were also proven necessary for the production of heterologous proteins in Pichia. The presence of at least $200 \mu \mathrm{M}$ copper was needed for optimal laccase activity [26].

There are several reports on expressing heterologous proteins in $P$. pastoris at low temperatures [11]. Incubation temperatures of $30,27,25$ and $23{ }^{\circ} \mathrm{C}$ have been examined in order to minimize extracellular proteolysis. 


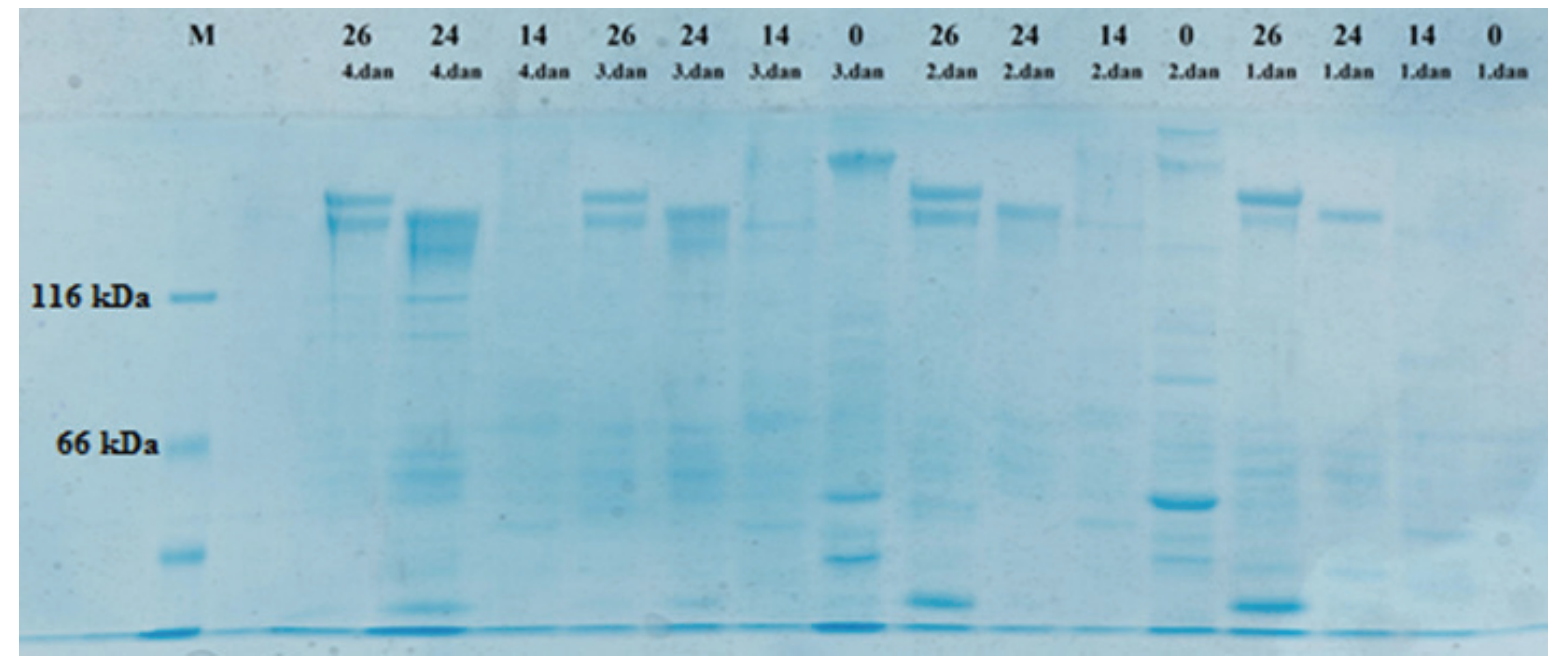

Fig. 8. SDS PAGE of fermentation liquid from samples after second fermentation of P.pastoris.

The kinetics of proteolytic reaction, in the presence or absence of cells, were shown to be influenced by $\mathrm{pH}$. Jahic et al. [27] reported that decreasing the $\mathrm{pH}$ from 5.0 to 4.0 in bioreactor cultures resulted in an increase in the fraction of full-length product from 40 to $90 \%$ during expression of cellulose-binding module in P. pastoris. The optimal $\mathrm{pH}$ would be determined best by running a series of fermentations at different $\mathrm{pH}$ values, therefore controlling the medium $\mathrm{pH}$ during the fermentation process is necessary. Optimum $\mathrm{pH}$ depends on individual properties of the protein, especially stability.

\section{Transformation of $S$. cerevisiae with the construct CHO- pYES}

S. cerevisiae strain InvSC1 was transformed with constructs CHO-pYES 14 and 15 . Only one colony had grown after 24 hours on the plate containing cells transformed with the construct 14, while on the plate containing the cells with construct 15 , two colonies grew (marked as: 15-1 and 15-2). Activity of each sample was determined after concentration but samples did not show any activity. However, the samples were further tested with SDS PAGE (Fig. 9).

The sample 15-2 showed a band corresponding to a molecular mass of about $110 \mathrm{kDa}$. This value is higher than the theoretical one, but given that only this sample differed from the empty vector and showed a band that was absent from other samples, we assumed that the band may derive from the desired enzyme, $\mathrm{CHO}$.

Glycosylation is one of the critical post-translation processing events in the synthesis of proteins. The role of glycosylation in protein folding, oligomer assembly, structural stability, specific signal transduction has been well documented [28]. Yeast and the highest eukaryotes utilize an evolutionarily conserved $\mathrm{N}$-linked oligosaccharide biosynthetic pathway that involves the formation of a Glc3Man9GIcNAc2-PP-dolichol lipidlinked precursor [29]. Subsequently, glycohydrolases in

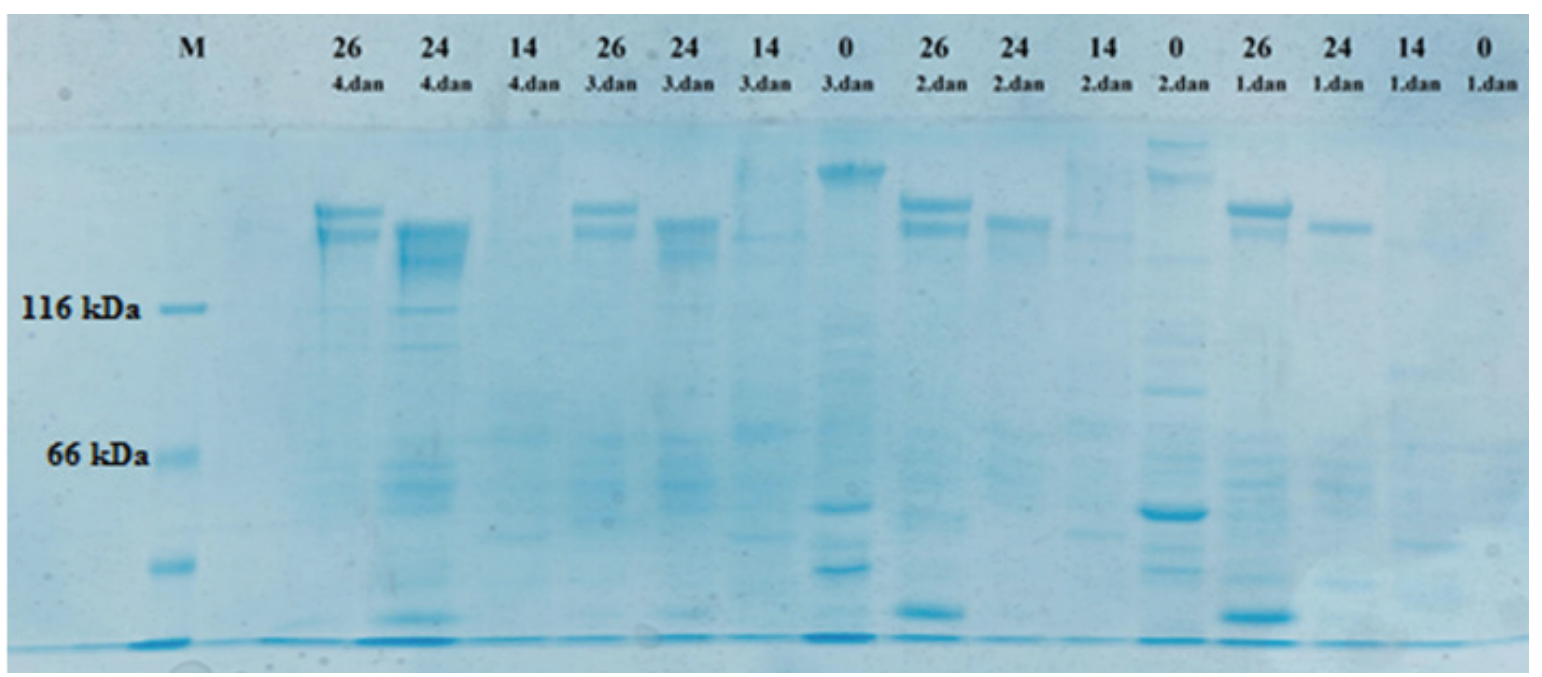

Fig. 9. SDS PAGE of samples obtained by fermentation of Saccharomyces cerevisiae. 
the endoplasmic reticulum remove the three glucoses and (with the exception of Schizosaccharomyces pombe) one specific mannose residue. Processing sugar transferases in the Golgi leads to the fomation of core-sized structure $\left(\operatorname{Hex}_{(<15)} \mathrm{GlcNac}_{(2)}\right)$ and cores with an extended poly- $\alpha 1$, 6-Man backbone [29]. The protein has to undergo all the mentioned post-translation modifications in order to obtain the correct conformation and any misstep in posttranslational modification pathway can cause the protein to be inactive.

Proteins may be susceptible to misfolding for a variety of reasons, including the formation of intermolecular disulfide bonds and exposure of their hydrophobic surfaces [11]. Intermolecular disulfide bonds are formed at higher temperatures when proteins are expressed in E. coli [30]. Lowering the cultivation temperature can be beneficial for reducing the proteolytic degradation of the recombinant proteins in the culture medium.

\section{CONCLUSIONS}

After cloning and heterologous expression of $\mathrm{CHO}$ in the $P$. pastoris expression system we have obtained several expressed protein bands with molecular weights over $116 \mathrm{kDa}$.

Cloning and heterologous expression of $\mathrm{CHO}$ in a $\mathrm{S}$. cerevisiae expression system, gave a protein that showed on SDS PAGE a molecular weight of about $110 \mathrm{kDa}$.

Bands obtained on the SDS PAGE had a higher molecular weight than theoretical. It is known that recombinant proteins, expressed in yeast, have higher molecular weights than expected due to the higher degree of glycosylation.

The resulting protein has shown no enzymatic activity in the ABTS assay and this may be due to inadequate folding of the protein in the expression system of $S$. cerevisiae. Further experiments on recombinant protein purification and refolding studies are necessary.

\section{Abbreviations}

ABTS - 2,2'-azinobis(3-ethylbenzthiazoline-6-sulfonic acid); $A D H$ - alcohol dehydrogenase; AOX - alcohol oxidase; APS - ammonium persulfate; $C B B$ - Coomassie Briliant Blue; $\mathrm{CHO}$ - carbohydrate oxidase; EDTA ethylenediamine-tetraacetic acid; FAD - flavin adenine dinucleotide; GAP - glyceraldehyde 3-phosphate dehydrogenase promoter; GOx - glucose oxidase; $\mathrm{HOx}$ - hexose oxidase; HPLC - high performance liquid chromatography; HRP - horseradish peroxidase; LB - Luria Broth medium; PAGE - polyacrylamide gel electrophoresis; SDS - sodium dodecyl sulfate; TCA - trichloroacetic acid; TEMED - 1,2-bis(dimethylamino)ethane; TRIS - tris(hydroxymethyl) aminomethane; YPD - yeast peptone dextrose.

\section{REFERENCES}

[1] J. Duskova, J. Dohnálek, T. Skálová, L. Henrik Østergaard, C. Crone Fuglsang, P. Kolenko, A. Štěpánková, J. Hašeka, Crystallization of carbohydrate oxidase from Microdochium nivale, Acta Crystallogr. Sect. F Struct. Biol. Cryst. Commun. 65 (2009) 638-640.

[2] D.P.H. Heuts, E.W. Van Hellemond, D.B. Janssen, M.W. Fraaije, Discovery, characterization, and kinetic analysis of an alditol oxidase from Streptomyces coelicolor, J. Biol. Chem. 282 (2007) 20283-20291.

[3] J.H. Custers, S.J. Harrison, M.B. Sela-Buurlage, E. Van Deventer, W. Lageweg, P.W. Howe, P.J. Van der Meijs, A.S. Ponstein, B.H. Simons, L.S. Melchers, M.H. Stuiver, Isolation and characterisation of a class of carbohydrate oxidases from higher plants, with a role in active defence, Plant J. 39 (2004) 147-160.

[4] M. Nordkvist, P.M. Nielsen, J. Villadsen, Oxidation of lactose to lactobionic acid by a Microdochium nivale carbohydrate oxidase: Kinetics and Operational Stability, Biotechnol. Bioeng. 97 (2006) 694-707.

[5] A. Ioannou, E. Cini, R.S. Timofte, S.L. Flitsch, N.J. Turner, B. Linclau, Heavily fluorinated carbohydrates as enzyme substrates: oxidation of tetrafluorinated galactose by galactose oxidase, Chem. Commun. 47 (2011) 11228-11230 .

[6] B. Savary, K.B. Hicks, J.V. O'Connor, Hexose oxidase from Chondrus crispus: improved purification using perfusion chromatography, Enzyme Microb Techn. 29 (2001) 42-51.

[7] Z. Fan, G.B. Oguntimein, P.J. Reilly, Characterization of Kinetics an Thermostability of Acremonium strictum Glucooligosaccharide Oxidase, Biotechn. Bioeng. 68 (2000): 231-237.

[8] M. Foumani, T.V. Vuong, E.R. Master, Altered Substrate Specificity of the Gluco-Oligosaccharide Oxidase From Acremonium strictum, Biotech. Bioeng. 108 (2011) 2261-2269.

[9] S. Pricelius, L. Ludwig, N.J. Lant, D. Haltrich, G.M. Guebitz, In situ generation of hydrogen peroxide by carbohydrate oxidase and cellobiose dehydrogenase for bleaching purposes, Biotechnol. J. 6 (2011) 224-230.

[10] M.A. Wolff, O.C. Hansen, O. Poulsen, Optimization of the Production of Chondrus crispus Hexose Oxidase in Pichia pastoris, Protein Express. Purif. 22 (2001) 189$-199$.

[11] P. Li, A. Anumanthan, X.G. Gao, K. Ilangovan, V.V. Suzara, N. Düzgüneş, V. Renugopalakrishnan, Expression of recombinant proteins in Pichia pastoris. Appl. Biochem. Biotechnol. 142 (2007) 105-124.

[12] G. Potvin, A. Ahmad, Z. Zhang, Bioprocess engineering aspects of heterologous protein production in Pichia pastoris: A review, Biochem. Eng. J. 64 (2012) 91-105.

[13] H. Hohenblum, N. Borth, D. Mattanovich, Assessing viability and cell-associated product of recombinant protein producing Pichia pastoris with flow cytometry, J. Biotechnol. 102 (2003) 281-290.

[14] A.L. Zhang, J.X. Luo, T.Y. Zhang, Y.W. Pan, Y.H. Tan, C.Y. Fu, F.Z. Tu, Recent advances on the GAP promoter deri- 
ved expression system of Pichia pastoris, Mol. Biol. Rep. 36 (2009) 1611-1619.

[15] S.M. Patrick, M.L. Fazenda, B. McNeil, L.M. Harvey, Heterologous protein production using the Pichia pastoris expression system, Yeast 22 (2005) 249-270.

[16] S. Shibasaki, M. Ueda, T. lizuka, M. Hirayama, Y. Ikeda, N. Kamasawa, M. Osumi, A. Tanaka, Quantitative evaluation of the enhanced green fluorescent protein displayed on the cell surface of Saccharomyces cerevisiae by fluorometric and confocal laser scanning microscopic analyses, Appl. Microbiol. Biotechnol. 55 (2001) 471$-475$.

[17] Y. Nakamura, S. Shibasaki, M. Ueda, A. Tanaka, H. Fukuda, A. Kondo, Development of novel whole-cell immunoadsorbents by yeast surface display of the IgGbinding domain, Appl. Microbiol. Biotechnol. 57 (2001) 500-505.

[18] E.H. Park, Y.M. Shin, Y.Y. Lim, T.H. Kwon, D.H. Kim, M.S. Yang, Expression of glucose oxidase by using recombinant yeast, J. Biotech. 81 (2000) 35-44.

[19] J.H. Ko, M.S. Hahm, H.A. Kang, S.W. Nam, B.H. Chung, Secretory expression and purification of Aspergillus niger glucose oxidase in Saccharomyces cerevisiae mutant deficient in PMR1 gene, Protein Express. Purif. 25 (2002) 488-493.

[20] C.T. Chung, S.L. Niemela, R.H. Miller, One-step preparation of competent Escherichia coli: transformation and storage of bacterial cells in the same solution, Proc. Natl. Acad. Sci. USA 86 (1989) 2172-2175.

[21] L. Sun, I.P. Petrounia, M. Yagasaki, G. Bandara, F.H. Arnold, Expression and stabilization of galactose oxidase in Escherichia coli by directed evolution, Protein Eng. 14 (2001) 699-704.
[22] U.K. Laemmli, Cleavage of structural proteins during the assembly of the head of bacteriophage T4, Nature 227 (1970) 680-685.

[23] L. Grinna, J. F. Tschop, Size distribution and general structural features of $\mathrm{N}$-linked oligosaccarides from the methyltrophic yeast Pichia pastoris, Yeast 5 (1989) 107$-115$.

[24] R.B. Trimble, P.H. Atkinson, J.F. Tschopp, R.R. Townsend, F. Maley, Structure of oligosaccharides on Saccharomyces SUC2 invertase secreted by the methylotrophic yeast Pichia pastoris, J. Biol .Chem. 266 (1991) 22807$-22817$.

[25] S.R. Hamilton, T.U. Gerngross, Glycosylation engineering in yeast: the advent of fully humanized yeast, Curr. Opin. Biotech. 18 (2007) 387-392.

[26] M. Jahic, M. Gustavsson, A.K. Jansen, M. Martinelle, S.O. Enfors, Stable linker peptides for a cellulose-binding domain-lipase fusion protein expressed in Pichia pastoris, J. Biotech. 102 (2003) 45-53.

[27] A. Wright, S.L. Morrison, Effect of glycosylation on antibody function: implications for genetic engineering, Trends Biotech. 15 (1997) 26-32.

[28] T.R. Gemmil, R.B. Trimble, Overview of $N$ - and $O$-linked oligosaccharide structures found in various yeast species, Biochim. Biophys. Acta 1426 (1999) 227-237.

[29] C.H. Schein, M.N.R. Noteborn, Formation of Soluble Recombinant Proteins in Escherichia coli is Favored by Lower Growth Temperature, Biotechnology (NY) 6 (1988) 291-294.

[30] S.C. Makrides, Strategies for achieving high-level expression of genes in Escherichia coli, Microbiol. Rev. 60 (1996) 512-538. 


\section{IZVOD}

\section{KLONIRANJE GENA ZA UGLENI HIDRAT OKSIDAZU IZ BILKE Lactuca sativa U KVASCE Saccharomyces cerevisiae I Pichia pastoris}

Vojin M. Tadić ${ }^{1}$, Ana Marija J. Balaž ${ }^{2}$, Marija P. Petrić ${ }^{1}$, Snežana M. Milošević ${ }^{1}$, Nevena D. Zelenović ${ }^{3}$, Martin Z. Raspor ${ }^{1}$, Jovan M. Tadić ${ }^{4}$, Radivoje M. Prodanović ${ }^{2}$

${ }^{1}$ Odeljenje za fiziologiju biljaka, Institut za biološka istraživanja "Siniša Stanković", Univerzitet u Beogradu, Bulevar despota Stefana 142, 11000 Beograd, Srbija

${ }^{2}$ Odeljenje za biohemiju, Hemijski fakultet, Univerzitet u Beogradu, Studentski trg 12-16, 11000 Beograd, Srbija

${ }^{3}$ Institut za hemiju, tehnologiju i metalurgiju, Univerzitet u Beogradu, Njegoševa 12, 11000 Beograd, Srbija

${ }^{4}$ Odeljenje za globalnu ekologiju, Carnegie Institution for Science, Stanford, CA 94305, USA

(Naučni rad)

Ugljeni hidrat-oksidaza ( $\mathrm{CHO}$ ) iz zelene salate (Lactuca sativa) je enzim koji je do danas nedovoljno ispitan. Vrlo se malo zna o njegovoj strukturi i funkciji. CHO pripada velikoj familiji ugljenihidrat-oksidaza, koje oksiduju šećere. Svaki od članova ove velike familije dobio je ime po supstratu koji oksiduje. Oksidaze iz ove familije enzima imaju kako sličnu ulogu tako i sličnu strukutru. Sve ili većina ovih enzima su monomeri, čiji se polipeptidni lanac uvija u dva domena. Jedan od domena vezuje flavinski kofaktor, a drugi domen je supstrat vezujući. Većina njih oksidaciju supstrata vrši po takozvanom ping-pong mehanizmu. Sve oksidaze iz karbohidrat-oksidaza familije, pa među njima i enzim koji je predmet ove studije (CHO), danas su našle veliku primenu u industriji. $\mathrm{CHO}$ se može primenjivati kako u medicinskoj djagnostici, konkretno u biosenzorima za određivanje glukoze u krvi, u prehrambenoj industriji, poljoprivredi, proizvodnji hleba, deterdženata i u raznim drugim industrijskim oblastima. Problem sa ovim enzimom, kao i sa ostalim članovima ove familije, jeste niska koncentracija u prirodnim izvorima. Zato su danas razvijene različite metode rekombinantne tehnologije, kojima se dobijaju ovi enzimi. U ovom radu opisano je kloniranje gena za $\mathrm{CHO}$ iz zelene salate u dve vrste kvasaca (Saccharomyces cerevisiae i Pichia pastoris). Sintetički gen za CHO (1821 bp) iz zelene salate kloniran je u vektor pUC57. Escherichia coli soj DH5 $\alpha$ korišćen je za kloniranje gena i održavanje plazmida. P. pastoris soj X-33 i S. cerevisiae soj InvSC1 korišćeni su za ekstracelularnu ekspresiju CHO. Aktivnost $\mathrm{CHO}$ određena je ABST esejom, a promena absorbance merena je na $405 \mathrm{~nm}$. Potvrda prisustva enzima rađena je na DNK agaroznoj elektroforezi i SDS-PAGE. Posle transformacije $P$. pastoris $\mathrm{X}-33$, nijedan od klonova nije pokazivao aktivnost $\mathrm{CHO}$. Posle prve fermentacije, kolonije su testirane na SDS-PAGE. Kako su dva uzorka pokazala trake, koje ne postoje na praznom vektoru, ove trake bi mogle odgovarati željenom enzimu, CHO. Traka se nalazi na molekulskoj masi koja je veća od teoretske (više od 120 kDa). Enzim bi mogao biti glikolizovan i zbog toga pokazivati ovako velike vrednosti za molekulsku masu. S. cerevisiae soj InvSC1 transformisan je konstruktom CHO-pZES. Posle 24 sata, tri kolonije su porasle na ploči na kojoj su bile ćelije transformisane pomenutim konstruktom. Uzorci su testirani na SDS-PAGE. Jedan uzorak je pokazao traku na oko 110 kDa, ali aktivnost $\mathrm{CHO}$ nije potvrđena takođe. Cilj ove studije je bio kloniranje $\mathrm{CHO}$ u kvascima $S$. cerevisiae i $P$. pastoris, kao i njena ekspresija u ovim, danas široko primenjivanim ekspresionim sistemima.
Ključne reči: Saccharomyces cerevisiae • Pichia pastoris • Glikozilacija 